\title{
Two agronomical aspects of Tagetes terniflora HBK for essential oil production
}

\author{
Miguel Ángel Serrato $\mathrm{Cruz}^{1^{*}}$, Francisco Díaz Cedillo${ }^{2}$, Daniel Hernández Medina ${ }^{1}$, \\ Arturo Curiel Rodríguez ${ }^{1}$

\footnotetext{
${ }^{1}$ Departamento de Fitotecnia, Universidad Autónoma de Chapingo, Carretera México-Texcoco, Chapingo, México;

*Corresponding Author: serratocruz@gmail.com

${ }^{2}$ Laboratorio de Química Orgánica, Escuela Nacional de Ciencias Biológicas, Instituto Politécnico Nacional, Prolongación de Carpio y Plan de Ayala s/n, Casco de Santo Tomás, México D.F., México
}

Received 28 September 2013; revised 6 November 2013; accepted 20 November 2013

Copyright (C 2014 Miguel Ángel Serrato Cruz et al. This is an open access article distributed under the Creative Commons Attribution License, which permits unrestricted use, distribution, and reproduction in any medium, provided the original work is properly cited. In accordance of the Creative Commons Attribution License all Copyrights (C) 2014 are reserved for SCIRP and the owner of the intellectual property Miguel Ángel Serrato Cruz et al. All Copyright @ 2014 are guarded by law and by SCIRP as a guardian.

\section{ABSTRACT}

The genus Tagetes is a possible source of essential oils for the biorational control of pests and diseases in Mexico. The aim of the present study was to assess the distance between plants (PD; $15 \times 80,30 \times 80$ and $60 \times 80 \mathrm{~cm}$ ) and urea fertilization $\left(0,60\right.$ and $\left.120 \mathrm{~kg} \cdot \mathrm{he}^{-1} \mathrm{~N}\right)$ for biomass production and essential oil in Tagetes terniflora HBK. Oil was obtained by the aerial part hydro-distillation and its chemical composition was analyzed by gas chromatography coupled to mass spectrometry. Factors N, PD and their interaction did not change plant height or the number of branches per plant; however, PD factor modified fresh tissue (FW) and dry tissue (DW) weights and the amount of oil per plant ( $p \leq 0.05)$ which represent a good biomass production (30 to 72.5 ton $\cdot \mathrm{he}^{-1} \mathrm{FW}, 11$ to 27 ton $\cdot \mathrm{he}^{-1} \mathrm{DW}$ ) and oil producing (168 to $383 \mathrm{~L} \cdot \mathrm{he}^{-1}$ ) potential in the field. Urea did not have effect on both biomass and oil response per plant but interaction of $15 \times 80 \mathrm{DP}$ and $120 \mathrm{~N}$ could favor higher biomass and oil production potential (78 ton'he ${ }^{-1} \mathrm{FW}, 28$ ton'he ${ }^{-1} \mathrm{DW}$ and $608 \mathrm{~L} \cdot \mathrm{he} \mathrm{e}^{-1}$, respectively). Essential oil yield varied from 0.3 to $2.1 \%$ according to the management conditions. A total of $\mathbf{1 1}$ major compounds were identified in essential oil, the relative quantity was constant in different agronomic management factors: Etagetone $(22 \%)$, cis-tagetenone $(20.4 \%)$, transtagetenone (20.4\%), dihydrotagetone (13.4\%) and cis- $\beta$-ocimene $(10.3 \%)$, trans- $\beta$-ocimene $(5.0 \%)$, propenyl anisole $(4.3 \%)$, sphatulenole
(1.1\%), allyl anisole (0.7\%), Z-tagetone (0.5\%) and limonene $(0.5 \%)$.

\section{KEYWORDS}

Tagetes terniflora; Biomass; Essential Oil; Chemical Composition; Distance between Plants; Nitrogen

\section{INTRODUCTION}

Essential oils extracted from aromatic plants are natural sources with broad-spectrum biological activity against insects, mites, nematodes, fungi and bacteria [1, 2]. The genus Tagetes (Asteraceae) consist of 58 species [3], most of them are aromatic species. The essential oil of T. terniflora HBK has a biological effect against lice Pediculus humanus capitis [4], weevils Sitophilus oryceae and Tribolium castaneum [5], flies Ceratitis capitata [6] and this essential oil also has a bactericidal effect [7]. The essential oil of T. terniflora has major compounds corresponding to monoterpenes, sesquiterpenes and phenylpropanoids $[6,8,9]$ their relative content depends on the phenological stage of the plant and the characteristics of the habitat [8].

T. terniflora is distributed in Peru and Argentina, and it has recently been found in Chiapas, Mexico, perhaps as an introduced species [10]. In South America, collected and natural habitat populations for oil extraction may have yields from $0.4 \%$ to $1.5 \%$ (mL/100g fresh tissue) or from $1.1 \%$ to $4.1 \%$ (dry base) [8]; so far there is no available information on agronomic management aspects of $T$. terniflora such as distance between plants and fertilization, which are important agronomic management 
factors for other species to improve biomass and essential oil $[11,12]$.

The presence of $T$. terniflora plants in Chiapas generates interest to grow and use them to control pest and diseases in Mexican agriculture. Therefore, the aims of the present study were to evaluate two agronomic management factors (population density and a nitrogen fertilization source) to generate preliminary information on biomass and essential oil production of this species.

\section{MATERIALS AND METHODS}

\subsection{Biological Material}

A total of 20 plants were grown under greenhouse conditions from seeds of T. terniflora collected in 2011 in San Cristóbal de las Casas, Chiapas, Mexico; seedlings were obtained from seeds of these plants to perform an experiment on agronomic management at Chapingo, Mexico in 2012 and to analyze the content of oil. "Eitzi Matuda" herbarium specimens provided by the Universidad de Ciencias y Artes de Chiapas, Mexico were analyzed for taxonomic identification of the species.

\subsection{Agronomic Management Factors, Variables and Statistical Analysis}

The present study was carried out at Chapingo, $19^{\circ} 29^{\prime}$ $\mathrm{N}$ and $98^{\circ} \mathrm{W}$, with an altitude of $2250 \mathrm{~m}$; subhumid temperate climate $(\mathrm{C}(\mathrm{w} 0)(\mathrm{W}) \mathrm{b}(\mathrm{i}) \mathrm{g})$; average annual rainfall of $654 \mathrm{~mm}$ and average temperature of $15^{\circ} \mathrm{C}$ with early frosts at the end of September and late frosts in April [13].

Sowing in greenhouse was carried out on April using germination trays of $3 \times 3 \mathrm{~cm}$ and $7 \mathrm{~cm}$ with peat moss (Cosmopeat) as substrate. Once the second pair of leaves was visible, the plant was transplanted (May), placing one plant per shrub between furrows with a spacing of 80 $\mathrm{cm}$ on moist soil. Before the field was plowed, the soil was left fallow and tilled. The field received heavy irrigation the same day after transplanting, two irrigations in May and then, the moisture supply was by temporary rain. The soil was mechanically tilled twice for weed control.

Three plant distances $(15 \times 80,30 \times 80$ and $60 \times 80$ $\mathrm{cm})$ and nitrogen fertilization with urea (46-00-00) at levels 0,60 and $120 \mathrm{~kg} \cdot \mathrm{e}^{-1}$ of nitrogen (units of $\mathrm{N}$ ) were tested. $\mathrm{N}$ was applied 30 days after transplanting. The experimental field was used for non-leguminous plants without using any fertilizer; no previous soil nutritional diagnosis was carried out.

Treatments were distributed in field according to a randomized block design with six replications in experimental plots of $12 \mathrm{~m}^{2}$; one plant corresponded to the experimental unit. Plants in full competition, in $100 \%$ flowering stage (150 days after transplanting) were consi- dered for evaluation. The plants selected were cut $2 \mathrm{~cm}$ below the ground level, immediately they were weighed and measured, each sample was place inside a paper bag and dried in an oven at $60^{\circ} \mathrm{C}$ for 3 days. The measured variables were: plant height, number of branches (from the first branch appearance at the base until the last visible branch at the apex; branches outside the main stem were not considered), fresh weight and dry weight of the aerial part and amount of essential oil per plant.

Data analysis was carried out using the following two-factor $(3 \times 4)$ completely randomized bock design: $y_{i j k}=\mu+\tau_{i}+\delta_{j}+\tau \delta_{i j}+\beta_{k}+\varepsilon_{i j k}$, where, $y_{i j k}=$ value of the dependent variable recorded in the experimental unit, in which the $i$-th dose of fertilization of the $j$-th distance of the transplanting distance of the $k$-th block was applied, $\mu=$ general average of all experimental plots for the conditions of the experiment, $\tau_{i}=$ effect to apply the $i$-th dose of fertilizer, $\delta_{j}=j$-th effect per transplanting distance, $\tau \delta_{i j}=$ combined effect of the levels of factors involved, $\beta_{k}=$ effect of the $k$-th block, and $\varepsilon_{i j k}=$ experimental error related to each $y_{i j k}$. The components of the model $\tau_{i}, \delta_{j}$ and $\tau \delta_{i j}$, are orthogonal to each other. The Student's test was used to compare means of each factor and of the combination of the factor levels for independent samples using a significant level of $\mathrm{p} \leq$ 0.05. Statistical analyzes were performed using SAS [14].

\section{Oil Extraction}

Oil was extracted from plants in full flowering stage using the methodology of hydro distillation reported by [15]. Three replications of each treatment were recorded to sample the production of oil; each sample corresponded to one plant cut into pieces of 1 to $3 \mathrm{~cm}$ and time of distillation was $45 \mathrm{~min}$.

\subsection{Determining Compounds}

The composition of essential oil was analyzed by gas chromatography coupled to mass spectrometry (CG-EM) using a Polaris Q Finnnigan Trace GC Ultra ${ }^{\circledR}$ equipment (USA) with a Polaris Q mass detector, electronic impact (70 eV). A column RTX-5MX, diphenyl-dimethylpolysiloxane (5:95), of $30 \mathrm{~m} \times 0.25 \mathrm{~mm} \varnothing$ (diameter) $\times 0.25$ $\mu \mathrm{m}$ was used. The injector and detector were set at 250 and $300^{\circ} \mathrm{C}$. The temperature of the oven started at $70^{\circ} \mathrm{C}$, and remained like this for $1 \mathrm{~min}$ and was programmed to reach $250^{\circ} \mathrm{C}$ at a rate of $20^{\circ} \mathrm{C} \mathrm{min}{ }^{-1}$. Helium was used as carrying gas, at a flow rate of $1 \mathrm{~mL} \mathrm{~min}^{-1}$. Diluted samples were injected manually (1/100 in methylene chloride $\mathrm{v} / \mathrm{v}$ ) of $1 \mu \mathrm{L}$, in split mode. Quantitative data were obtained electronically from the area percentage of the chromatographic peak. Detected mass range was 35 $500 \mathrm{~m} / \mathrm{z}$. N-alkanes are used as references in the calculation of Kovats indices. Three processed samples were measured in the identification of the components by 
comparing the relative retention indices and mass spectra using the NIST database of the GC-MS system and Adams's data published by Corp. Carol Stream, USA [16].

\section{RESULTS AND DISCUSSION}

\subsection{Distance between Plants and Fertilization}

According to the F-test of the analysis of variance, plant height (160 to $188 \mathrm{~cm}$ ) and the amount of branches per plant (23 to 47) of $T$. terniflora in $100 \%$ flowering did not change their expression due to the agronomic management factors evaluated (individual and interaction effects), an opposite result to that observed in other species of Tagetes subject to the application of nitrogen fertilizer and population densities [17,18]. However, biomass production and essential oil were strongly changed by plant distance (PD) (Table 1), underlining that by increasing the plant distance, increased fresh and dry tissue biomass (66\% in $60 \times 80$ and from $32 \%$ to $37 \%$ in $30 \times 80$, with respect to that recorded with $15 \times 80$ ) and the amount of oil $(76 \%$ in $60 \times 80$ and $10 \%$ in $30 \times 80$ with respect to that recorded with $15 \times 80$ ) (Table 1 ), a trend that has been recorded in previous studies, in which different species of Tagetes have been studied [12,17]. The urea as a nitrogen source did not cause significant effects on the amount of biomass and plant oil (Table 1), this was not expected considering that some researches $[12,18]$ confirm that by increasing the units of this nutrient, also increases the growth of the plant, as total biomass. Perhaps the rapid dissolution of urea in the soil, and if it was once used, contributed to a low availability of nitrogen during the 150 days that plants were kept on the field until harvest, time when the experiment data was recorded; there is also a strong suspicion that tilling the soil (fallowing, ploughing, furrowing, weeding), rather than the application of urea in the doses tested, largely influenced the growth of T. terniflora, an agricultural practice that in the case of other wild species of Tagetes provokes a biomass increase up to $300 \%$ with respect to the non-tilling system [19]. The experimental verification of the cases referred is required, and also the testing of other nitrogen sources and dosages to evaluate their effect on biomass and oil production of T. terniflora.

Although F-test indicated significant effects of PD $\times \mathrm{N}$ there was not a clear tendency of interactions and only few ones favored the expression of the biomass as plants were further apart (Table 1), for example, applying 120 $\mathrm{N}$, with a plant distance of $15 \times 80$ less fresh or dry tissue was produced (945 g/plant and 339 g/plant, respectively) than with a plant distance of $60 \times 80$ (1175 g/ plant and $445 \mathrm{~g} /$ plant, respectively) (Table 1), this trend
Table 1. Responses per plant in biomass (fresh and dry) and volume of oil of T. terniflora set at different plant distances (PD) and doses of urea as nitrogen $(\mathrm{N})$ source at Chapingo, Mexico.

\begin{tabular}{|c|c|c|c|c|}
\hline \multirow{2}{*}{$\begin{array}{l}\text { Distance }(\mathrm{cm}) \\
\text { between plants }\end{array}$} & \multicolumn{3}{|c|}{ Nitrogen units (N) } & \multirow{2}{*}{$\begin{array}{l}\text { Average } \\
\text { (PD) }{ }^{9}\end{array}$} \\
\hline & 0 & 60 & 120 & \\
\hline \multicolumn{5}{|c|}{ Fresh tissue per plant $(\mathrm{g})(\mathrm{PD} \times \mathrm{N})^{\dagger}$} \\
\hline $15 \times 80$ & 917.9 bcd & $679.2 \mathrm{~d}$ & 944.9 bcd & $871.2 \mathrm{C}$ \\
\hline $30 \times 80$ & $1433.1 \mathrm{ab}$ & $878.1 \mathrm{~cd}$ & $1032.2 \mathrm{abcd}$ & 1150.4 B \\
\hline $60 \times 80$ & $1416.9 \mathrm{abc}$ & $1368.6 \mathrm{abc}$ & 1548.5 a & $1444.7 \mathrm{~A}$ \\
\hline Average $(\mathrm{N})^{\pi}$ & $1255.9 \mathrm{~A}$ & 975.3 B & $1175.2 \mathrm{AB}$ & \\
\hline \multicolumn{5}{|c|}{ Dry tissue per plant $(\mathrm{g})(\mathrm{PD} \times \mathrm{N})$} \\
\hline $15 \times 80$ & 343.8 de & 259.6 e & 339.0 de & $322.7 \mathrm{C}$ \\
\hline $30 \times 80$ & 597.3 a & 328.2 de & 401.9 cde & $43.8 \mathrm{~B}$ \\
\hline $60 \times 80$ & $540.1 \mathrm{abc}$ & 475.8 abcd & $596.5 \mathrm{ab}$ & $537.4 \mathrm{~A}$ \\
\hline Average (N) & $483.7 \mathrm{~A}$ & $354.5 \mathrm{C}$ & $445.8 \mathrm{AB}$ & \\
\hline \multicolumn{5}{|c|}{ Essential oil per plant $(\mathrm{mL})(\mathrm{PD} \times \mathrm{N})$} \\
\hline $15 \times 80$ & $3.2 \mathrm{~d}$ & $4.3 \mathrm{~cd}$ & $7.3 \mathrm{abc}$ & $4.6 \mathrm{~B}$ \\
\hline $30 \times 80$ & 6.7 abcd & $5.2 \mathrm{bcd}$ & $5.4 \mathrm{bcd}$ & $5.5 \mathrm{~B}$ \\
\hline $60 \times 80$ & $8.7 \mathrm{ab}$ & 7.0 abcd & 9.3 a & $8.1 \mathrm{~A}$ \\
\hline Average (N) & $6.1 \mathrm{~A}$ & $5.5 \mathrm{~A}$ & $7.3 \mathrm{~A}$ & \\
\hline
\end{tabular}

${ }^{\dagger}$ Means with different lower case letters are significantly different $(p \leq 0.05)$. "Means with different capital letters are significantly different $(\mathrm{p} \leq 0.05)$.

was also observed for the amount of oil per plant without applying $\mathrm{N}$ (Table 1). Other interactions showed that by increasing $\mathrm{N}$ with a PD of $15 \times 80$, increased the oil per plant $(3.2 \mathrm{~mL}$ without $\mathrm{N}, 4.3 \mathrm{~mL}$ with $60 \mathrm{~N}$ and $7.3 \mathrm{~mL}$ with $120 \mathrm{~N}$ ), this suggests the importance of taking into account the specific management conditions to obtain desired results. For example, in the case of PD of $15 \times 80$ without $\mathrm{N}$ (case 1 ), and $60 \times 80$ with $120 \mathrm{~N}$ (case 2), the lowest (3.2 mL, $918 \mathrm{~g})$ and highest (9.3 mL, $1548 \mathrm{~g})$ amount of oil and fresh biomass per plant obtained, respectively, suggests that, in a production per hectare (10 $000 \mathrm{~m}^{2}$ ), the case (1) could favor the production of fresh biomass of 76 ton and a volume of oil of $266 \mathrm{~L}$; however in case (2) 32 ton and $193 \mathrm{~L}$ could be produced (Table 2).

Oil yield from $0.3 \%$ to $0.8 \%$ on fresh base and from 0.9 to $2.1 \%$ on dry base (Table 3 ) obtained from different management conditions evaluated, is located within the yield limits allocated for South American populations of T. terniflora in $100 \%$ flowering stage without any management [8]; it is necessary to determine the yield in other phenological phases, such as fruiting where a higher yield is possible [8].

\subsection{Essential Oil Composition}

A total of 11 compounds in greater proportion with retention times were detected according to the fragmentation pattern in the following sequence: limonene (3.94 $\mathrm{min}$ ), cis- $\beta$-ocimene (3.95 min), dihydrotagetone (4.1 $\mathrm{min})$, Z-tagetone (4.5 $\mathrm{min})$, trans- $\beta$-ocimene (4.75 $\mathrm{min}$ ), Etagetone (5.01 $\mathrm{min})$, alilanisole (5.55 $\mathrm{min})$, cis-tagetenone 
Table 2. Extrapolation of biomass and oil produced per plant at yield per hectare of $T$. terniflora established at Chapingo, Mexico by the management of two agronomic factors.

\begin{tabular}{ccccc}
\hline \multirow{2}{*}{$\begin{array}{c}\text { Plants.he } \\
\text { (Distance) }\end{array}$} & $\begin{array}{c}\text { Level of N } \\
\left(\mathrm{kg}^{-1} \mathrm{he}^{-1}\right)\end{array}$ & $\begin{array}{c}\text { Yresh tissue } \\
\text { (ton) }\end{array}$ & $\begin{array}{c}\text { Dry tissue } \\
\text { (ton) }\end{array}$ & Oil (L) \\
\hline \multirow{2}{*}{83325} & 0 & 76.4 & 28.6 & 266.6 \\
$(15 \times 80)$ & 60 & 56.5 & 21.6 & 358.2 \\
& 120 & 78.7 & 28.2 & 608.2 \\
41662 & 0 & 59.7 & 24.8 & 279.1 \\
$(30 \times 80)$ & 60 & 36.5 & 14.0 & 216.6 \\
& 120 & 42.8 & 16.7 & 224.9 \\
20831 & 0 & 29.5 & 11.2 & 166.6 \\
$(60 \times 80)$ & 60 & 28.5 & 9.8 & 145.8 \\
& 120 & 32.2 & 12.5 & 193.7 \\
\hline
\end{tabular}

Table 3. Yield response of essential oil of T. terniflora plants at Chapingo, Mexico at two management factors.

\begin{tabular}{|c|c|c|c|}
\hline \multirow{2}{*}{ Population density } & \multicolumn{3}{|c|}{ Applying urea $\left(\mathrm{kg} \cdot \mathrm{he}^{-1} \mathrm{~N}\right)$} \\
\hline & 0 & 60 & 120 \\
\hline Plant distance & \multicolumn{3}{|c|}{ Oil yield \% (ml/100 gr tissue: fresh/dry) } \\
\hline $15 \times 80$ & $0.34 / 0.93$ & $0.63 / 1.65$ & $0.77 / 2.15$ \\
\hline $30 \times 80$ & $0.46 / 1.12$ & $0.59 / 1.58$ & $0.52 / 1.34$ \\
\hline $60 \times 80$ & $0.61 / 1.61$ & $0.51 / 1.47$ & $0.79 / 1.56$ \\
\hline
\end{tabular}

(5.72 $\mathrm{min})$, trans-tagetenone (5.8 $\mathrm{min})$, propenyl anisole (6.34 min) and spathulenol (7.18 min) (Figure 1). Four groups of compounds stood out according to the relative percentage: abundant 20\% to 22\% (E-tagetone, cis- and trans-tagetenone), moderately abundant $10 \%$ to $13 \%$ (dihydrotagetone, cis- $\beta$-ocimene), less abundant $4 \%$ to $5 \%$ (propenyl anisole, trans- $\beta$-ocimene) and very less abundant $0.5 \%$ to $1 \%$ (Z-tagetone, limonene, allyl anisole, spathulenol). Secondary metabolites found in the present study had already been identified in previous work $[6,8$, $9,20]$ where it is stated that the group of monoterpenes (ocimene, tagetone and tagetenone) is more abundant that phenylpropanoids (propenyl anisole and alyl anisole) and sesquiterpenes (spathulenol and limonene) groups, as also found in this study.

The relative abundance of each compound in essential oil of $T$. terniflora population grown for the first time in the area of Chapingo, Mexico was different with respect to that recorded for the same species in populations of different geographic origin $[6,20]$, which is possibly due to environmental or genetic causes.

The presence of these secondary metabolites and similar relative amount of them in essential oil in samples analyzed corresponding to the plants grown in the experiment with the various agronomic management factors were responses that had previously been found in other wild species of Tagetes introduced to cultivation subjected to different dates of establishment in the field [21], at population densities and nitrogen amounts [12].

This result is important because now there is information available of some management aspects in field conditions that can help to have a quality control of the oil produced, however, it is recommended to continue with the study of other management factors such as date of establishment.

The extrapolation of biomass yield and oil per hectare (Table 2), good estimated yields of oil (Table 3) and a relatively homogeneous composition of the essential oil of $T$. terniflora on management conditions established (Figure 1), form a basic reference for: experiences of commercial production to validate the important management factors found in this study, tests of other fertilizers and nitrogen sources such as phosphorus and potassium that could improve the productivity of $T$. terniflora and toxicological studies against the various pests and diseases of important crops in the region of the upper valleys of Estado de México, state where Chapingo is located.

\section{CONCLUSION}

The distance between plants, but not the application of nitrogen in the form of urea, influences the production of biomass and essential oil per plant of T. terniflora, some interactions also influenced the production of biomass and oil. Oil yield varied according to the management conditions. A total of 11 compounds were identified in essential oil with abundance of the tagetone and tagetenone groups, followed by ocimene, phenylpropanoids, spathulenol and limonene; the relative amount of each chemical component did not showed changes under the

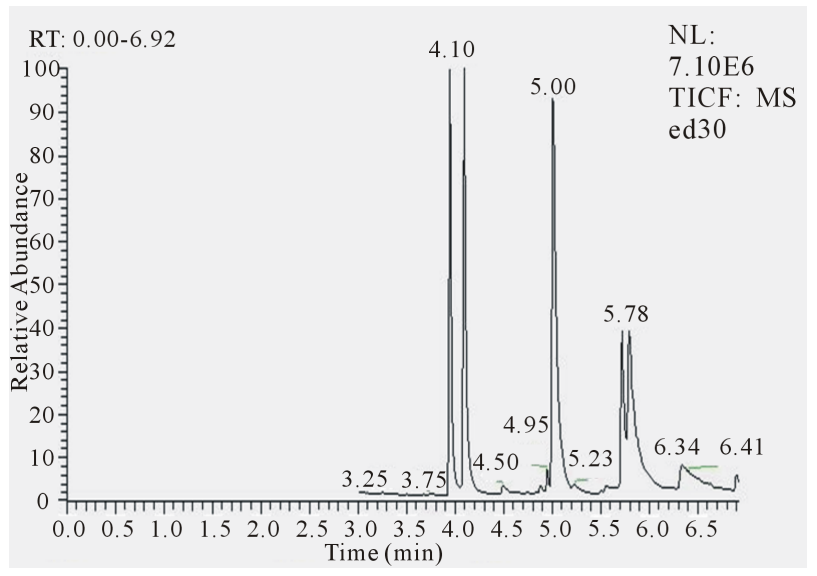

Figure 1. Chromatogram with signals corresponding to limonene (Retention time, Rt, 3.94), cis- $\beta$-ocimene (Rt, 3.95), dihydrotagetone (Rt, 4.1), Z-tagetone (Rt, 4.5), trans- $\beta$-ocimene (Rt, 4.75), E-tagetone (Rt, 5.01), alyl anisole (Rt, 5.55), cis-tagetenone (Rt, 5.72), trans-tagetenone (Rt, 5.8), propenyl anisole (Rt, 6.34) and spathulenol (Rt, 7.18) present in essential oil of $T$. terniflora grown at Chapingo, Mexico. 
different agronomic conditions.

\section{REFERENCES}

[1] Bakkali, S., Averbeck, S., Averbeck, D. and Idaomar, M. (2008) Biological effects of essential oils-A review. Food and Chemical Toxicology, 46, 446-475. http://dx.doi.org/10.1016/j.fct.2007.09.106

[2] Tripathi, A., Upadhyay, S., Bhuiyan, M. and Bhattacharya, P. (2009) A review on prospects of essential oils as biopesticide in insect-pest management. Journal of Pharmacognosy and Phytotherapy, 1, 52-63.

[3] Soule, J. (1996) Novel annual and perennial Tagetes. In: Janick, J., Ed., Progress in New Crops, ASHS Press, Arlington, 546-551.

[4] Gutiérrez, M.M., Stefanazzi, N., Werdin, G.J., Benzi, V. and Ferrero, A.A. (2009) Actividad fumigante de aceites esenciales de Schinus molle (Anacardiaceae) y Tagetes terniflora (Asteraceae) sobre adultos de Pediculus humanus capitis (Insecta; Anoplura; Pediculidae). Boletín Latinoamericano y del Caribe de Plantas Medicinales y Aromáticas, 8, 176-179.

[5] Stefanazzi, N., Stadler, T. and Ferrero, A. (2011) Composition and toxic, repellent and feeding deterrent activity of essential oils against the stored-grain pests Tribolium castaneum (Coleoptera: Tenebrionidae) and Sitophilus oryzae (Coleoptera: Curculionidae). Pest Management Science, 67, 639-646. http://dx.doi.org/10.1002/ps.2102

[6] López, B., López, M., Aragón, L., Tereschuk, M., Slaris, A., Feresin, G., Zygadlo, J. and Tapia, A. (2011) Composition and anti-insect activity of essential oils from $\mathrm{Ta}$ getes L. species (Asteraceae, Helenieae) on Ceratitis capitata Wiedermann and Triatoma infestans Klug. Journal of Agronomy and Food Chemistry, 59, 5286-5292. http://dx.doi.org/10.1021/jf104966b

[7] Tereschuk, M.L., Baigorí, M.D. and Abdala, L.R. (2003) Antibacterial activity of Tagetes terniflora. Fitoterapia, 74, 404-406. http://dx.doi.org/10.1016/S0367-326X(03)00043-1

[8] Saavedra, N., Cosme, W., Viturro, C., Molina, A. and Molina, S.G. (2003) Ensayo piloto de extracción de volátiles de Tagetes terniflora HBK.

http://www.efn.unc.edu.ar/otros/bibliocentro/index_archi vos/31-Tagetes.pdf

[9] De Feo, V., Urrunaga-Soria, E., Urrunaga-Soria, R. and Pizza, C. (2005) Composition and in vitro toxicity of the essential oil of Tagetes terniflora HBK (Asteraceae). Flavour and Fragrance Journal, 20, 89-92. http://dx.doi.org/10.1002/ffj.1379
[10] Turner, B. (1996) The comps of mexico-A systematic account of the family Asteraceae. Tageteae and Anthemideae. Phytologia Memoirs, 6, 1-93.

[11] Ramesh, K. and Singh, V. (2008) Effect of planting date on growth, development, aerial biomass partioning and essential oil productivity of wild marigold (Tagetes minuta) in mid hills of Indian western Himalaya. Industrial Crops and Products, 27, 380-384. http://dx.doi.org/10.1016/j.indcrop.2007.08.004

[12] Campos-Muñiz, M., Medina-Pitalúa, J.L. and SerratoCruz, M.A. (2010) Aspectos agronómicos para la producción de anís de monte (Tagetes filifolia Lag.) en temporal en ocuituco, morelos. Revista Fitotecnia Mexicana, 33, 97-105.

[13] García, E. (1998) Modificaciones al sistema de clasificación climática de Köppen. Instituto de Geografía, UNAM, México.

[14] Statistical Analysis System (SAS) (2004) SAS/STAT 9.1 user's guide. SAS Publishing, Cary.

[15] Serrato-Cruz, M.A., Díaz-Cedillo, F. and Barajas-Pérez, J.S. (2008) Composición del aceite esencial en germoplasma de Tagetes filifolia Lag. de la región centro-sur de México. Agrociencia, 42, 277-285.

[16] Adams, P. (2001) Identification of essential oils components by gas chromatography/quadrupole. Mass spectroscopy. Allured Publishing Corporation Carol Stream.

[17] Serrato-Cruz, M.A. (2003) Aspectos del cultivo de dos especies de Tagetes productoras de aceites esenciales. Naturaleza y Desarrollo, 1, 15-22.

[18] Pushkar, N.S., Rathore, S.V.S. and Upadhayay, D.K. (2008) Response of chemicals and biofertilizer on growth and yield of African marigold (Tagetes erecta L.) cv. Pusa Narangi Gaida. Asian Journal of Horticulture, 3, 130 132.

[19] Serrato-Cruz, M.A. (2005) Efectos del ambiente de domesticación en dos especies silvestres del género Tagetes en México. Plant Genetic Resources Newsletter, 142, 2128.

[20] Zygadlo, J.A., Abburra, R.E., Maestri, D.M., Guzman, C.A., Grosso, N.R. and Ariza, L. (1993) Essential oil composition of Tagetes ternifora HBK and Tagetes laxa Cabrera. Flavour and Fragrance Journal, 8, 273-275. http://dx.doi.org/10.1002/ffj.2730080507

[21] Serrato-Cruz, M.A., Díaz-Cedillo, F. and Barajas-Pérez, J.S. (2005) Seasonal influence on phenology and essential oil content of Tagetes filifolia Lag. Annalen der Meteorologie, 41, 82-85. 